\title{
Örgütsel Etik İklim Algısının Çalışan Sesliliği Davranışına Etkisinde Psikolojik Güvenliğin Aracı Etkisi: Vakıf Üniversitelerine Yönelik Bir Araştırma
}

\author{
The Mediating Effect of Psychological Safety in the Effect of Organizational Ethical \\ Climate Perception on Employee Voice Behavior: A Research on Foundation \\ Universities
}

Ahmet Tuncay ERDEM *

\section{$\ddot{O} Z$}

Bu araştırmanın temel amacı pozitif örgütsel davranış konusu olan örgütsel etik iklim algısının çalışan sesliliğine etkisinde, "psikolojik güvenin”" aracı bir rol oynayıp oynamadı̆̆ının belirlenmesidir. Araştırmada örgütsel etik ikliminin çalışan sesliliğine etkisinde "psikolojik güvenlik" algısının aracı bir rolü var mıdır sorusu cevaplandırılmaya çalışılmaktadır. Araştırma nicel araştırma yöntemine göre kurgulanmış ve genel tarama modellerinden ilişkisel tarama modeline göre desenlenmiştir. Araştırma hipotezlerinin test edilebilmesi için Konya ilindeki iki adet vakı üniversitesinde görev yapmakta olan idari personellere yönelik basit tesadüfi örnekleme tekniğine göre veriler toplanmış ve toplanan verilere AMOS ve SPSS programlarıla betimsel ve istatistiksel analizler yapılmıştır. Araştırma verilerinin analizinden elde edilen bulgulara göre örgütsel etik iklimi, çalışan sesliliği pozitif yönde etkilemek, söz konusu etkileşimde psikolojik güvenlik algısı kısmi olarak aracı rol oynamaktadır. Örgütsel etik ikliminin olduğu işyerlerinde çalışan sesliliği artmakta, bu etkileşimde psikolojik güvenlik algısı çalışan sesliliğini güçlendirmektedir. Bu bulgular işgörenlerin etik iklim, seslilik ve güven algılarının birbirini destekleyen örgütsel ve psikolojik duygu durumları olduğunu göstermektedir.

ANAHTAR KELIMELER

Örgütsel Etik İklim, Çalışan Sesliliği, Psikolojik Güvenlik, Aracı Etki

\begin{abstract}
The main purpose of this study is to determine whether "psychological trust" plays a mediating role in the effect of the perception of organizational ethical climate, which is the subject of positive organizational behavior, on employee voices. In the study, it is tried to answer the question whether "psychological trust" perception has a mediating role in the effect of organizational ethical climate on employee voice. The research has been structured according to the quantitative research method and it has research designed according to the relational scanning model, one of the general scanning models. In order to test the research hypotheses, data have been collected according to the simple random sampling technique for administrative staff working in two foundation universities in Konya, and descriptive and statistical analyzes have been made with AMOS and SPSS programs. According to the findings obtained from the analysis of the research data, the organizational ethical climate positively affects employee vocalism and the psychological safety perception partially plays a mediating role in this interaction. Employee voices increase in workplaces with an organizational ethical climate, and the perception of psychological safety in this interaction strengthens employee voice. These findings show that employees' perceptions of ethical climate, loudness and trust are organizational and psychological emotional states that support each other.
\end{abstract}

\section{KEYWORDS}

Organizational Ethical Climate, Employee Voices, Organizational Safety, Mediating Effect

\begin{tabular}{|c|c|c|}
\hline \multicolumn{2}{|r|}{$\begin{array}{c}\text { Makale Geliş Tarihi / Submission Date } \\
28.11 .2020\end{array}$} & $\begin{array}{c}\text { Makale Kabul Tarihi / Date of Acceptance } \\
11.01 .2021\end{array}$ \\
\hline Atıf & $\begin{array}{l}\text { Erdem, A. T. (2021). Örgütsel Etik İ } \\
\text { Aracı Etkisi: Vakıf Üniversitelerine Y } \\
\text { Dergisi, } 24 \text { (1), 57-70. }\end{array}$ & $\begin{array}{l}\text { Sesliliğ̣i Davranışına Etkisinde Psikolojik Güvenliğin } \\
\text { elçuk Üniversitesi Sosyal Bilimler Meslek Yüksekokulu }\end{array}$ \\
\hline
\end{tabular}

\footnotetext{
* Dr. Öğr. Üyesi, Bolu Abant İzzet Baysal Üniversitesi İletişim Fakültesi, ahmeterdem @ibu.edu.tr, ORCID: 0000-0003-4573-8415
} 


\section{GİRIŞ}

Aristotelesin belirttiği gibi insanlar doğaları gereği iletişim halinde bulunmak isteyen sosyal varlıklardır ve bu çerçevede insanların hayatlarını devam ettirebilmeleri noktasında bir takım fiziki ve psikolojik ihtiyaçlarının bulunduğu söylenebilir. Örgütlerin sosyal sistemler olması nedeniyle örgüt çalışanlarının da insani durumları gereği sosyalleşme ihtiyaçları olarak iletişim ve etkileşim halinde olmaları beklenir. Ancak çalışanlar diğer insanlarla yeterince iletişim kuramadıklarında veya fikirlerini istedikleri gibi dile getiremedikleri durumlarda örgütte verimli çalışamayacaklar ve performans düşüklüğü yaşayacaklardır. Bu noktada çalışanlarda sessizlik başlayacak ve örgüte aidiyet azalacaktır. Diğer yandan örgütte çalışanların görüşlerine önem verilmesi durumunda ve yönetsel kararlar alınırken çalışanların da fikirlerinin alınmasıyla örgütte güven iklimi oluşacak ve çalışanlarda verimlilik sağlanabilecektir.

Örgütlerde etik iklim, çalışanların etik kurallar dâhilinde neyi yapmaları neyi de yapmamaları gerektiği konusunda bir yol gösterici olmakla birlikte çalışanlar örgüt iklimini gözlemlemek suretiyle karşılaştıkları etik ikilemde hangi davranışların etik hangi davranışların etik olmadığını bilerek nasıl tutum sergileyecekleri konusunda kararlar verebileceklerdir (Soyalın, 2019: 1). Bu noktada her örgütte bulunması gereken etik ilkelerin uygulanması öncelikle yöneticiler tarafından yapılması ve daha sonra çalışanlar tarafından benimsenip uygulanması gerekmektedir. Bu doğrultuda örgütte tam olarak tesis edilen örgütsel etik iklimiyle çalışanlar neleri yapıp nelerden kaçınmaları gerektiğini de görebileceklerdir. Etik iklimiyle işgörenler görev ve sorumluluklarını layıkıyla bildikleri sürece psikolojik güvenlik algıları yükselecek ve örgütte çalışan sesliliği artacaktır. Bu çerçevede etik iklim ve psikolojik güvenin örgütlerde olumlu etkileri olarak çalışan sesliliği örnek verilebilir.

Örgütte etik iklimi tesis edilemez ve çalışanların psikolojik güvenlik algılarının düşük olması durumunda, çalışanlar fikirlerini söylemekten kaçınacaklar ve örgütün yanlış yönetimi ve işleyişi noktasında sessiz kalacaklardır. Ryan ve Oestreich (1991) Amerika'daki 22 örgütte toplam 260 işgörenle yaptığı araştırmada \%70 oranındaki çalışanın örgütte karşılaştıkları sorunlar hakkında konuşmaktan ve fikir belirtmekten korktukları sonucuna ulaşmıştır. Bu durumdaki örgütleri olumsuz yönde etkileyen örgütsel sessizlik davranışının görülmesi kaçınılmaz olacaktır. Diğer yandan Milliken ve diğ. (2003) tarafından gerçekleştirilen bir araştırmada örgütteki çalışanların \%85'i hatalar ve olumsuzluklar karşısında üst yönetime düşüncelerini söylemeyerek sessiz kalmaktadır. Bu sorunların da örgütlerde etik iklimin hâkim olamamasından ve çalışanlarda yeterince güven algısının oluşmamasından kaynaklandığı düşünülmektedir.

Çalışan sesliliği literatürde genel olarak çalışanların örgütte bireysel olarak görüşlerini ifade etmeleri üzerine odaklanmaktadır (Morrison, 2011; 2014; Kaufman, 2015; Lam vd., 2016; Lee vd., 2017; Qi ve Liu, 2017; Prasadika ve Nishanthi, 2018; Peng ve Wei, 2019; Thohiroh ve Satrya, 2019; Dahl, 2020; Miao vd., 2020). Örgütlerde çalışanların duygu ve düşüncelerini rahat bir biçimde ifade etme zorluğu öteden beri gelen bir sorun olarak görülebilir. Bununla birlikte öğütte söz sahibi olmayan çalışanlar kendilerini değersiz görerek sessizlik davranışlarını da sergiledikleri bilinir. Bu kapsamda araştırmada çalışan sesliliğinin sağlayabileceği örgütsel etik iklimi ve psikolojik güvenlik algıs1 konuları üzerinde durulması gerekli görülmüştür. Araştırmanın sorunu örgütlerde çalışanların yeterince düşüncelerini ifade edememeleri nedeniyle olumsuz davranışlara ve verimsiz çalışmalara yönelebilmelerinin örgütleri olumsuz yönde etkilemesidir. Bu doğrultuda örgütte etik ikliminin tesis edilmesiyle çalışanların fikirlerini beyan etmeleri noktasında kendilerini rahat ve güvende hissetmeleri gerekliliği ile araştırma yapılmıştır. Bu çerçevede araştırmanın temel amacı; örgütsel etik iklimi, çalı̧̧an sesliliği ve psikolojik güvenlik etkileşimlerini analiz etmek olup araştırmanın sorusu "örgütsel etik ikliminin çalışan sesliliğine etkisinde "psikolojik güven" algısının aracı bir rolü var mıdır" şeklinde belirlenmiştir. Araştırma sorusunu cevaplayabilmek için Konya ilindeki iki adet vakıf üniversitesinde görev yapmakta olan idari personellere yönelik uygulama yapılmıştır. Vakıf üniversitesi idari personellerinin araştırma örnekleminde seçilmesinin temel sebebi bu kişilere gerek yönetim tarafından ve gerekse kurumun sahipleri tarafından yeterince söz hakkı tanınmadığı düşüncesidir. Ayrıca bu çalışanlarda çalışan sesliliğini etkileyen kavramın neler olabileceğinin belirlenmesi gerekliliği de örneklemin seçilmesinde etkili olmuştur.

Bilimsel bilgilerin önceki araştırmacıların ortaya koymuş oldukları deneyim ve bilgilere dayalı olarak ortaya çıkması nedeniyle bilimsel araştırmaların teorik yaklaşımlara dayandırılması gerekmektedir (Tutar ve Erdem, 2020: 123). Bu kapsamda araştırmanın kuramsal temeli Sosyal Mübadele Kuramı' na dayandırılmıştır.

\section{KAVRAMSAL ÇERÇEVE ve HIPOTEZLER}

\section{1. Örgütsel Etik İklimi}

Etik, Yunancadan türeyen bir sözcük olup "ethos" kelimesinden türetilmiş, "karakter" anlamında kullanılmaktadır ve doğru davranışın yanlış davranıştan ayrılmasında bir yol gösterici olarak ahlak kavramını 
anlama arayışı olarak nitelendirilmektedir (Kızbaz, 2016: 230). Etik, yaşanmak istenen hayata yönelik bir araştırma, bu çabaya yönelik belirlenen amaçların yerine getirilmesinde arayış ve neyin yapılması neyin yapılmamasının gerektiğinin belirlenmesinde rehber niteliğindedir (Aydın, 2001).

Etik iklimi bir kavram olarak örgüt iklimi ile etik kavramlarının kesişiminde bulunmaktadır ve etik kavramının temelinde ahlak olgusu yer almaktadır (Sezgili ve Efeoğlu, 2020: 3620). Etik iklimi ahlaki davranışlardan beslenen örgütsel değerleri, işlemleri ve uygulamaları içermekle birlikte, etik konularının neler olduğundan örgütlemede etik kavramının değinildiği algılara kadar geniş bir çerçeve oluşturmaktadır (Cullen vd., 2003: 131). Diğer bir ifadeyle örgütsel etik iklimi, örgüt faaliyetleri esnasında yapılan işlerin ahlaki temellere dayandırılarak yürütülme biçimini ortaya koymaktadır (Tuna ve Yeşiltaş, 2014: 105).

Örgütsel etik iklimi, çalışanların görev yaptıkları örgütte var olduklarına inandıkları etik prosedürler ile politikalar hakkında anlamlı psikolojik algıları olmakla birlikte bu algılar örgütte çalışanların paylaştıkları anlamlı psikolojik algılar, tutum veya duygulara değil doğrudan gözlemlere dayanmaktadır (Doğan ve Kılıç, 2014: 271). Wimbush ve Shepard (1994: 638)'a göre çalışanların yaptıkları bu gözlemler, örgütte herhangi bir etik ihlali durumunda veya çalışanların etik ikilemde kalmaları durumunda bunu nasıl algılayıp çözüme ulaştıracaklarına dair yol gösterici olarak kullanılmaktadır. Etik iklimi, örgütlerde meydana gelen etik sorunlarla çalışanların nasıl başa çıkacaklarını ve etik yönden doğru davranış tarzlarının neler olduğu konusunda örgütün ortak algılamaları olarak da ifade edilmektedir (Akdoğan ve Demirtaş, 2014: 110). Bu kapsamda örgütün algıladığı etik iklimi, etik konulara yönelik takip edilen formal ya da formal olmayan beklentiler ve süreçleri içermektedir (Victor ve Cullen, 1988: 107). Bu kapsamda örgüt bünyesinde birçok iş iklimi bulunmasına rağmen örgütün etik iklimi çalışanların etik davranışlarını şekillendirmesi açısından önemlidir (DeConinck, 2011: 618).

Etik iklimi, örgütlerin sürdürebilirliklerini sağlamada ve iş faaliyetlerinde başarı elde edebilmelerinde önemlidir. Örgütte etik bir görüş geliştirmek, olası sorunların belirlenip çözülmesinde kolaylık sağlayacak, olay ve sorunlara farklı açılardan yaklaşılmasına imkân tanınarak karar alma sürecinde yönetici için bir yol gösterici olacaktır (Johnson, 2009). Bu kapsamda örgütlerde etik iklimi çalışanların uymaları gereken kurallar bütünü olup bu kuralları ahlakla biçimlendirme şekli olarak da düşünülebilir. Örgütlerde etik ikliminin önemi çerçevesinde Trevino ve diğ. (1998), örgütlerin etik davranışları teşvik etmeleri durumunda çalışanların davranışlarını etik kurallara göre şekillendirme zorunlulukları hissedeceklerini ve bu durum da çalışanların örgütlerine daha fazla aidiyet hissetmelerinin sağlanacağını belirtmektedir. Ayrıca yöneticilerin etik iklimi benimseyerek bu konu hakkında yeterli bilgiye sahip olmaları durumunda çalışanlar arasında etik davranış yaygınlaşarak elde edilen bu katkı politika ve uygulamalara da yansıyacaktır. Haldorai ve diğ. (2020) örgütlerde gerek çalışanların ve gerekse yöneticilerin örgütsel etik konularını algılamalarının önemli olduğunu belirterek yöneticilerin yönetim tarzlarını etik kurallara göre belirlememeleri durumunda çalışanların da etik değerlere fazla önem vermeyeceklerini, bu durumun da etik olmayan durumların ortaya çıkmasına neden olacağını belirtmektedir.

\section{2. Çalışan Sesliliği}

Çalışan sesliliği; örgüt faaliyetlerinin iyileştirilmesi amacıyla işle ilgili çalışanların; öneri, eleştiri, endişe ve fikirlerini özgür bir biçimde gönüllü olarak yöneticilerle veya arkadaşlarıyla paylaşmaları durumu olarak tanımlanmaktadır (Morrison, 2011: 374). Literatürde çalışan sesliliği ile ilgili yapılan ilk araştırma Hirschman (1970) tarafından Nijerya demiryolu çalışanlarına yönelik yapılmış olup, araştırmada çalışan sesliliği kavramını örgütte meydana gelen sakıncalı durumlardan kaçmak yerine sorunların üzerine giderek değişimde bulunma olarak nitelendirilmiştir. Rusbult ve diğ. (1982) sesliliği, örgütlerde sorunlar karşısında aktif ve yapıcı bir çözüm bulma yöntemi olarak belirterek sendika gibi sivil toplum kuruluşlarından yardım istemek, örgütün diğer çalışanlarından yardım istemek ve iş şartlarını iyileştirme çabalarının bütünü olarak tanımlamaktadır. $\mathrm{Bu}$ kapsamda çalışan sesliliği literatürde genel olarak örgütte bireysel görüşlerin açık bir şekilde ifade edilmesi üzerine odaklanmaktadır (Tangirala ve Ramanujam, 2008: 1189; Morrison, 2014: 174; Kaufman, 2015: 24; Alfayad ve Arif, 2017; Nazir vd., 2020: 3; Rubbab ve Naqvi, 2020).

Çalışan sesliliği, örgütlerde çalışanların işleriyle ilgili konularda görüş belirtmeleri ve bunu bilinçli olarak gerçekleştirmeleridir (Dyne vd., 2003: 1361). Çalışanların görüş ve önerilerinde örgüt yönetimini eleştirmek yerine örgütü geliştirmeye yönelik yenilikçi çabaları içermektedir. Diğer bir ifadeyle seslilik, çalışanların olumlu ve yapıcı fikirlerini açıkça belirtmesini desteklemek ve çalışanların bunu zorlama karşısında değil isteyerek yapması faaliyetleri olarak da nitelendirilmektedir (Trevino vd., 1998: 1190; Morrison, 2011: 375).

Çalışan sesliliğii, çalışanların iş̧leriyle ilgili tavsiyelerini beyan etme, örgüt yöneticileriyle sorunları tartışarak çözüm bulmaya yönelik fikir beyan etme, şikâyetleri iletme durumu olarak görülerek örgütte yanlış 
giden durumları çalışanların rahatlıkla söyleyebilmeleri olarak da ifade edilir (Saunders, 1992: 189). Çalışan sesliliğiyle, çalışanlar düşüncelerini açıkça belirterek örgütte yenilik ve gelişime ilişkin fursatları ortaya çıkarabileceklerdir. $\mathrm{Bu}$ durumun tersine yöneticiler çalı̧̧anların sesliliklerine önem vermezlerse veya yöneticilerin umursamazlıkları nedeniyle çalışanlar bir sonuç göremezlerse görüşlerini söylemeyi birakacaklardır (Landau, 2009: 4).

Örgütte çalışan sesliliğini üç kategoriye ayıran Saunders ve diğ. (1992)'e göre seslilik; savunmacı seslilik, kabullenici seslilik ve olumlu sesliliktir. Savunmacı seslilik, örgütte bireyin kendini savunma kaygısıyla görüşlerini belirtmesidir. Kabullenici seslilik, bireyin örgütte diğer kişilerle fikir birliğine varması ve diğerlerinin desteğini alması durumudur. Olumlu seslilik, çalışanların tüm örgütün çıkarlarını korumaya yönelik çözüm önerileri, bilgi alış verişleri, görüş ve fikirlerin yapıcı bir şekilde açıkça belirtilmesidir (Dyne vd., 2003: 1361).

Çalışan sesliliği örgütleri birçok yönden olumlu olarak etkilemektedir. Çalışanların fikirlerini açıkça dile getirmeleri ile örgütlerde daha isabetli kararlar alınarak hatalar en aza indirilmekte (Morrison ve Milliken, 2000), çalışan verimliliğini teşvik ederek örgütlerde performans artışına (Morrison, 2014: 175) imkân sağlamaktadır. Diğer yandan çalışan sesliliğiyle örgütsel bağlılık artarak iş tatmini sağlanmakta ve örgütsel verimlilik artmaktadır (Whiting vd., 2012; Alfayad ve Arif, 2017; Prasadika ve Nishanthi, 2018; Dahl, 2020; Wang vd., 2020).

Çalışan sesliliğinin azaltılması veya yok edilmesi durumlarında örgütlerde işten ayrılma niyeti artmakta, tükenmişlik duygusu yaşanmaktadır (Lam vd., 2016; Thohiroh ve Satrya, 2019). Diğer taraftan yöneticilerin örgütte çalışan sesliliğini teşvik etmesiyle çalışanların örgüt amaçlarını benimsemeleri sağlanarak örgüte bağl1lıklarını da arttıracaktır (Farndale vd., 2011: 115)

\subsection{Psikolojik Güvenlik}

Güvenlik, örgütteki bireylerin davranışlarına yönelik sınırlılıklarını bilmeleri, tahmin edilebilir, açık, tutarlı ve tehdit edici nitelikte olmayan durumlar olarak belirtilmektedir (Rich vd., 2006: 496). Psikolojik güvenlik, bireylerin imajlarının, kariyerlerinin ve sosyal statülerinin olumsuz olarak etkilenmesinden korkmayarak kendilerini örgüt veya toplum içerisinde gösterebilme çaba ve istekleri olarak da ifade edilmektedir (Kahn, 1990: 708). Edmondson (2002), psikolojik güvenlik kavramın1, bireylerin içerisinde bulundukları ortamlarda, diğer kişilerle karşılaşabilecekleri riskler açısından değerlendirerek bu risklerin sonuçları ile ilgili algıları olarak ifade etmekle birlikte çalışanların cezalandırılmadan görüşlerini serbestçe paylaşmaları açısından kendilerini güvende ve saygın hissetme durumları olarak da nitelendirmektedir.

Örgütlerde psikolojik güvenlik, çalışanlar arasındaki risk algısı olarak da tanımlanmaktadır (Edmondson, 2002). Bu görüşe göre örgütlerde çalışanların psikolojik güvenlik algılarının olumsuz yönde etkilenmesinde etken faktörün çalışanlar arasındaki risklerin olduğu belirtilmektedir. Bu doğrultuda yapılan araştırmalarda örgütlerde psikolojik güvenlik algısının gelişmişlik düzeyi çalışanların risk algılarının da düşmesine sebep olmaktadır (Chen vd., 2019b). Çalışanlar örgütte kişisel amaçlarına ulaşmada ne kadar az engelle karşılaşırlarsa o kadar psikolojik olarak kendilerini güvende hissedeceklerdir (May vd., 2004: 159). Buna ek olarak çalışanlar örgütlerini güvenli bir ortam olarak algıladıkları sürece hatalarından ders çıkarabilecekler ve yöneticilerin suçlamalarıyla karşılaşmadan hata ve başarısızlıklarını rahatlıkla dile getirip düzeltebileceklerdir (Hirak vd., 2012). Bu kapsamda çalışanlar, psikolojik anlamda kendilerini güvende hissettikleri örgütlerde çalışmalarıyla kişisel düşüncelerini rahatlıkla dile getirebileceklerdir. Düşüncelerinden dolay1 aşağılanmayacaklarını bildikleri için utanç duygusu da yaşamayacaklardır (Edmondson ve Lei, 2014: 25). Bununla birlikte örgütlerdeki faaliyetlerin ve davranış biçimlerinin tutarlı, açık, tahmin edilebilir ve tehdit edici olmaması durumlarında güven ortamından söz edilebilirken, bu durumun tam tersi olan durumlarda; tutarsızlık, belirsizlik, tahmin edilemeyen ve tehdit edici olan durumlarda çalışanlar güvensizlik hissedeceklerdir (Kahn, 1990: 708).

\section{4. Örgütsel Etik İklimi, Çalışan Sesliliği ve Psikolojik Güvenlik İlişkileri}

Araştırma kuramsal dayanak olarak sosyal mübadele kuramına dayandırılmaktadır. Örgütlerdeki bireylerin karşılıklı sosyal ve ekonomik değişim içerisinde oldukları bilinmekle birlikte tarafların birbirlerinin beklentilerini karşılamaları durumunda sosyal mübadele ilişkisi meydana gelmektedir (Ertürk, 2014: 15). Bu kapsamda sosyal mübadele ilişkisinde gönüllülük temel alınarak tarafların birbirleriyle kaynak değişiminde bulunmaları sağlanmaktdır (Soyalın, 2019: 80). Taraflar birbirlerinin beklentilerini tatmin ettikleri sürece sosyal mübadele ilişkisi devam eder. Bu karşılıklı yarar sağlama durumunda tarafların ilişkileri sürmektedir (Waskito vd., 2020). Diğer yandan örgütlerde etik ikliminin oluşturulmasıyla çalışanların davranışlarında düzen tesis edilecek ve tarafların karşılıklı ilişkileri ve beklentileri de belirli etik kurallar doğrultusunda 
düzenlenmiş olacaktır. Sosyal mübadele teorisini örgütlerde bilgi paylaşımıyla ilişkilendiren Soyalın (2019: 80)'a göre örgütlerde çalışanlar arasındaki bilgi paylaşımı karşılıklı güven ortamının oluşması durumunda meydana gelmektedir. Güven ortamının örgütlerde tesis edilmesiyle de hem bilgi paylaşımı meydana gelecek hem de çalışanlar arasında iş tatmini sağlanabilecektir. Bu çerçevede çalışanlar görüşlerini açık bir biçimde söyleyerek çalışan sesliliğini meydana getirebileceklerdir (Soyalın, 2019: 80). Sonuç olarak örgütlerde etik ikliminin sağlanmasıyla çalışanlarda psikolojik güven arttırılacak ve bu sayede taraflar düşüncelerini rahatlıkla ve açık bir şekilde beyan edebileceklerdir. Teori kapsamında örgüt taraflarının karşılıklı menfaatleri tatmin edilerek çalışan sesliliğinin arttırılacağı düşünülmektedir.

Çalışan sesliliği, örgütlerde çalışanların açıkça konuşmaları, fikirlerini belirtmeleri, belirli bir konuyu benimsetme davranışı, sorumluluk alma, yenilikçi tutumlar ile örgüte fayda sağlamaya yönelik davranışların bütünü olarak ifade edilmektedir (Çiftçi ve Gürer, 2019: 25). Bu kapsamda çalışan sesliliği, örgütü olumlu yönde etkileyen faydacı bir davranış olarak görülmektedir. Diğer yandan örgütlerde çalışan sesliliğini etkileyen faktörler bulunmakla birlikte bu faktörlerden en önemlileri arasında örgütlerin yönetim şekilleri ile çalışma biçimlerine yönelik örgüt iklimi bulunmaktadır. Bu noktada etik değerlerin önemsendiği ve çalışanların etik kurallara teşvik edildiği örgütlerde çalışan sesliliğinin görülmesi muhtemeldir (Soyalın, 2019: 102). Üst yönetimin çalışanların fikirlerini beyan etmeleri noktasında destekleyici ve önem verici olmasıyla çalışan sesliliği artacak, örgüt işleyişiyle ilgili sorunların çözümüne yönelik kendilerine de söz hakk1 verildiğine inana çalışanlar sayesinde örgütte olumlu bir iklim oluşacaktır (Bowen ve Blackmon, 2003: 1397). Walumbwa ve Schaubroeck (2009: 1277)'a göre örgütte etik ilkelere uyan yöneticiler ve liderler çalışanlara olumlu yönde örnek olacaktır ve örgütsel etik ikliminin hâkim olduğu örgütlerde çalışanların görüş ve önerileri önemsenecek ve bu durumda çalışanlar teşvik edilecektir. Peterson (2002: 49)'a göre etik iklim örgütte doğru davranışların neler olduğunu göstermekle birlikte etik sorunlar karşısında örgütlerin neler yapmaları gerektiğini de göstererek etik dışı davranışları azaltacaktadır. Elçi ve Alpkan (2006)'a göre örgütlerde çalışanların var olan ilke ve süreçlere yönelik edinmiş oldukları ortak yargıları etik iklimini oluşturmaktadır. Örgütte etik iklim, çalışanların çoklu sesliliğiyle meydana gelen bir durum olmakla birlikte çalışanların ortak görüşlerine yönelik meydana getirilen örgütsel etik kurallarla faaliyette bulunan örgütler daha verimli olabileceklerdir.

Örgütlerde etik ikliminin hâkim olmasıyla çalışanlar etik ikliminde çalıştıklarını algılayarak görüşlerini daha fazla seslendirme yoluna gideceklerdir (Brown ve Treviño, 2006). Bu doğrultuda Meydan ve diğ. (2016: 146) bir eğitim kurumu çalışanlarına yönelik yaptıkları araştırmada çalışanların etik ikilem karşısında kalmaları durumunda etik kuralların bir rehber niteliğinde olacağını ve etik iklimi oluşan örgütlerde çalışanların fikirlerini söylemede istekli olacaklarını belirlemişlerdir. Brown ve diğ. (2005) örgütte meydana gelen sorunların çalışanlar tarafından yöneticilere iletilmesi durumunda örgütsel sessizlik davranışının da azalacağını belirtmektedir. Bu kapsamda çalışanların, örgütsel etiğin hâkim olduğu örgütlerde çalıştıklarına yönelik algılarının artması ve yöneticilerin etik davranış sergilemeleri gibi durumlarında örgütte etik iklim tesis edilecek ve kurallara uyan çalışanlarda örgütsel sessizlik azalacaktır (Brown ve Treviño, 2006). Bu bilgiler doğrultusunda araştırmanın ilk hipotezi aşağıdaki gibi kurgulanmıştır;

H1: Örgütsel etik iklimi çalışan sesliliğini pozitif yönde etkilemektedir.

Psikolojik güvenlik, örgütlerde çalı̧̧anların kendilerini güvende hissetmeleri ve yenilik faaliyetlerini gerçekleştirebilmeleri için gereklidir (Schein ve Bennis, 1965). Güvenlik temelde belirsizlik ve değişimlerin çalışanlarda oluşturduğu olumsuz algıları gidererek bireyler arasındaki riski azaltmaktadır (Edmondson ve Lei, 2014: 28). Pearsall ve Ellis (2011: 403)'e göre çalışanlar, örgütte kendilerini psikolojik olarak güvende hissettiklerinde, fikirlerini söylediklerinde ve bundan zarar görmeyeceklerini düşündüklerinde yaptıkları hataları kabul etme ve çalışma arkadaşları tarafından ortaya konulan alternatiflere hoşgörülü olup saygı duyma eğiliminde olacaklardır. Ayrıca literatürde psikolojik güvenliğin çalışan sesliliğini pozitif yönde etkilediği çalı̧̧malar (Ashford vd., 1998; Burris vd., 2008; Walumbwa ve Schaubroeck, 2009) da bulunmaktadır. Bu doğrultuda araştırmanın ikinci hipotezi aşağıdaki şekilde belirlenmiştir.

H2: Psikolojik güvenlik çalışan sesliliğini pozitif yönde etkilemektedir.

Örgütlerin etkili faaliyet göstermelerinde etik davranışların önemli rolünün olmasıyla birlikte ancak etik davranışların biçimlendirdiği örgüt ortamlarında güvenlik kavramından bahsedilebilir (Chen vd., 2019a: 975). Örgütün amacına yönelik iyi tanımlanan etik ilkelerle yönetilen örgütlerde çalışanlar birbirleriyle güven ilişskisinde çalışma imkânı bularak daha verimli bir şekilde faaliyet sürdürebileceklerdir (Öztürk ve Coşkun, 2000: 159). Bu noktada örgütteki yöneticilerin güvenli örgüt iklimi oluşturmaları durumunda örgüt iklimi etik olarak nitelendirilebilecektir. Aksi takdirde örgütte güven tesis edilemeyecek ve çalışanlar kendilerini güvende hissedemeyeceklerdir (Carnevale, 1988: 4). Ring ve Van de Ven (1992: 465) yaptıkları araştırma ile etik 
iklimin hâkim olduğu örgütlerde güvenin de olumlu yönde etkileneceği sonucuna ulaşarak örgütlerde etik iklimin olması gerektiğini belirtmektedirler. Bu kapsamda araştırmanın üçüncü hipotezi aşağıdaki biçimde belirlenmiştir.

H3: Örgütsel etik iklimi psikolojik güvenliği pozitif yönde etkilemektedir.

Araştırmada aracı değişken olarak belirlenen psikolojik güvenlik; çalışanların örgütte etkili ve verimli bir biçimde çalışabilmeleri için öğrenme ihtiyaçlarını, kendilerinden şüphe ettikleri durumları ve endişelerini özgürce ifade etmeleri durumları olarak ifade edilmektedir (Kahn, 1990: 708). Güvenlik duygusu örgütte etik iklimle doğru orantılı olarak artacak ve bu durum çalışan sesliliğine dönüşerek örgüt ortamında verimlilik artışına neden olacaktır. $\mathrm{Bu}$ doğrultuda literatürde psikolojik güvenliğin aracılık rolüne ilişkin yapılan araştırmalarda (Kahn, 1990; Walumbwa ve Schaubroeck, 2009; Erkutlu ve Chafra, 2015; Sağnak, 2017) psikolojik güven aracı etki rolü oynamaktadır. Literatürde örgütsel etik ikliminin çalışan sesliliğine etkisinde psikolojik güvenin aracı rol oynadığı iki araştırmaya (Soyalın, 2019; Soyalin ve Karabey, 2020) rastlanılmış olup bu araştırmalarda da psikolojik güvenin aracı rol oynadığ görülmüştür. Bu doğrultuda araştırmanın dördüncü ve son hipotezi aşağıdaki şekilde belirlenmiştir,

H4: Örgütsel etik ikliminin çalışan sesliliğine etkisinde psikolojik güvenlik aracı rol oynamaktadır.

Araştırma kapsamında değişkenlere yönelik teorik model ile hipotezleri Şekil 1'deki gibi kurgulanmıştır. Modelde "Örgütsel Etik İklimi” bağımsız değişken, "Çalışan Sesliliği” bağımlı değişken ve "Psikolojik Güvenlik" ise aracı değişken olarak belirlenmiş̧ir.

\section{Şekil 1: Araştırma Modeli}

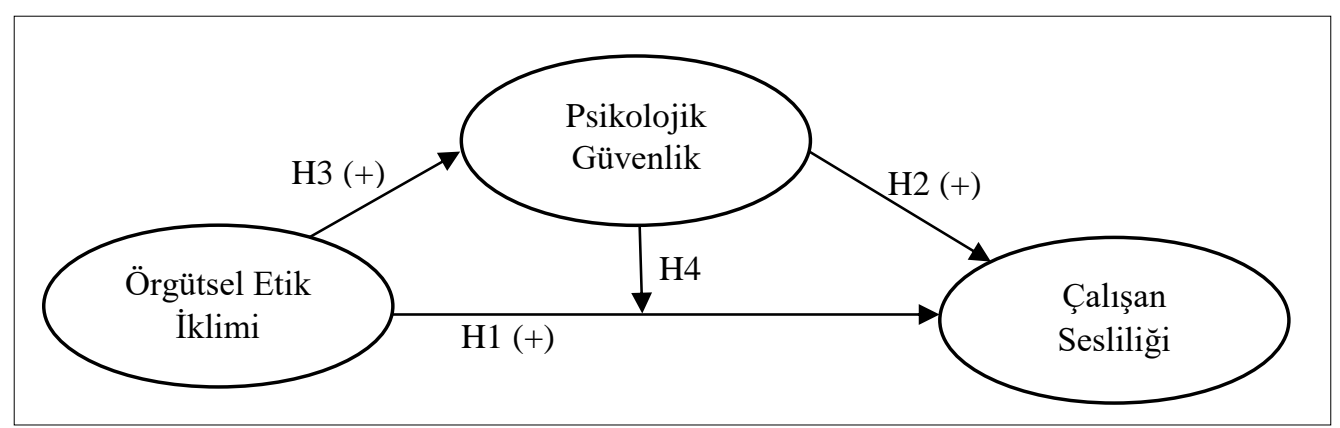

\section{YÖNTEM}

Bilimsel bir araştırmada evrendeki olay ve olguların belirlenmesi amacıyla sistematik bir biçimde araştırma modeli ve hipotezler geliştirilmeli ve kurgulanan hipotezler bilimsel bir araştırma metoduyla test edilmelidir (Tutar ve Erdem, 2020: 71). Bu çerçevede sistematik bir süreç olarak araştırmanın bilimsel yöntemi nicel araştırma olarak belirlenmiştir.

Bilimsel bir araştırmanın deseni, araştırma kapsamında belirlenmiş araştırma sorusunu cevaplayabilmek ve belirlenmiş hipotezleri test edebilmek için rehber görevi görmektedir (Tutar ve Erdem, 2020: 77). Bu çerçevede araştırmada genel tarama modelinden yola çıkılarak ilişkisel tarama modeline doğru desenlenen bir araştırma kurgulanmıştır. Araştırma model ve hipotezleri nicel araştırma yöntemiyle, elde edilen veriler analizlere tabi tutularak test edilmeye çalışılmış ve bu analiz sistematik bir süreç izlenerek yapılmıştır.

\subsection{Evren ve Örneklem}

Çalışmanın evrenini Konya ilinde faaliyet gösteren vakıf üniversitelerinde çalışan idari personeller oluşturmaktadır. Araştırmada, süre ve maddi kısıtlar nedeniyle iki adet vakıf üniversitesinden örneklem seçimi yapılmıştır. Bu kapsamda araştırmanın örneklemini Konya ilinde faaliyette bulunan iki adet vakıf üniversitesinde idari işlemleri yürütmek üzere görev yapmakta olan 341 idari personeller oluşturmaktadır. Bu doğrultuda üniversitelerin idari personellerine yönelik tesadüfî örnekleme yöntemiyle 304 adet anket dağıtılmış, 289 kullanılabilir anket formu elde edilmiştir. Araştırmada tesadüfi örneklem yönteminin seçilmesinin sebebi, evrenin bir kısmını temsil eden katılımcıların eşit seçilme şansına göre tesadüfi örneklemi seçmektir (Tutar ve Erdem, 2020: 246). Elde edilen analiz edilebilir anket miktarına göre anketlerin geri dönüş oranları \%84,8'dir. Bu orana göre örneklemin evreni temsil etme gücünün yeterli olduğu görülmektedir (Baş, 2003: 43).

Araştırma verileri 01.05.2019 - 27.05.2019 tarihleri arasında ilgili üniversitelerden elde edilmiştir. 


\subsection{Veri Toplama Aracı}

Araştırmanın birinci ölçeği 19 ifadeden oluşan "Örgütsel Etik İklimi Ölçeği” Arnaud (2010) tarafından geliştirilmiştir. Araştırmanın ikinci ölçeği olan "Çalışan Sesliliği Ölçeği” 10 ifadeden oluşmaktadır ve Liang ve diğ. (2012) tarafından geliştirilmiştir. Araştırmanın son ölçeği olan "Psikolojik Güvenlik Ölçeği”" ise Liang ve diğg. (2012) tarafindan oluşturulmuştur. Bu ölçek 5 ifadeden oluşmaktadır.

\subsection{Geçerlilik ve Güvenirlik}

Araştırmada kullanılan ölçeklere yönelik yapılan güvenilirlik analizinde örgütsel etik iklimi ölçeği için $\alpha=0.940$, psikolojik güvenlik ölçeği için $\alpha=0.954$ ve çalışan sesliliği ölçeği için $\alpha=0.893$ olarak belirlenmiştir. $\mathrm{Bu}$ sonuçlara göre ölçeklerin güvenilir olduğu görülmektedir.

Araştırma modelinde ele alınan örgütsel etik iklimi, psikolojik güvenlik ve çalışan sesliliği ölçeklerinin güvenilirlik ve geçerliliklerini belirleyebilmek için ölçüm modeline doğrulayıcı faktör analizi (DFA) uygulanmıştır (Şekil 2).

\section{Şekil 2: Modele ilişkin Doğrulayıcı Faktör Analizi Diyagramı}

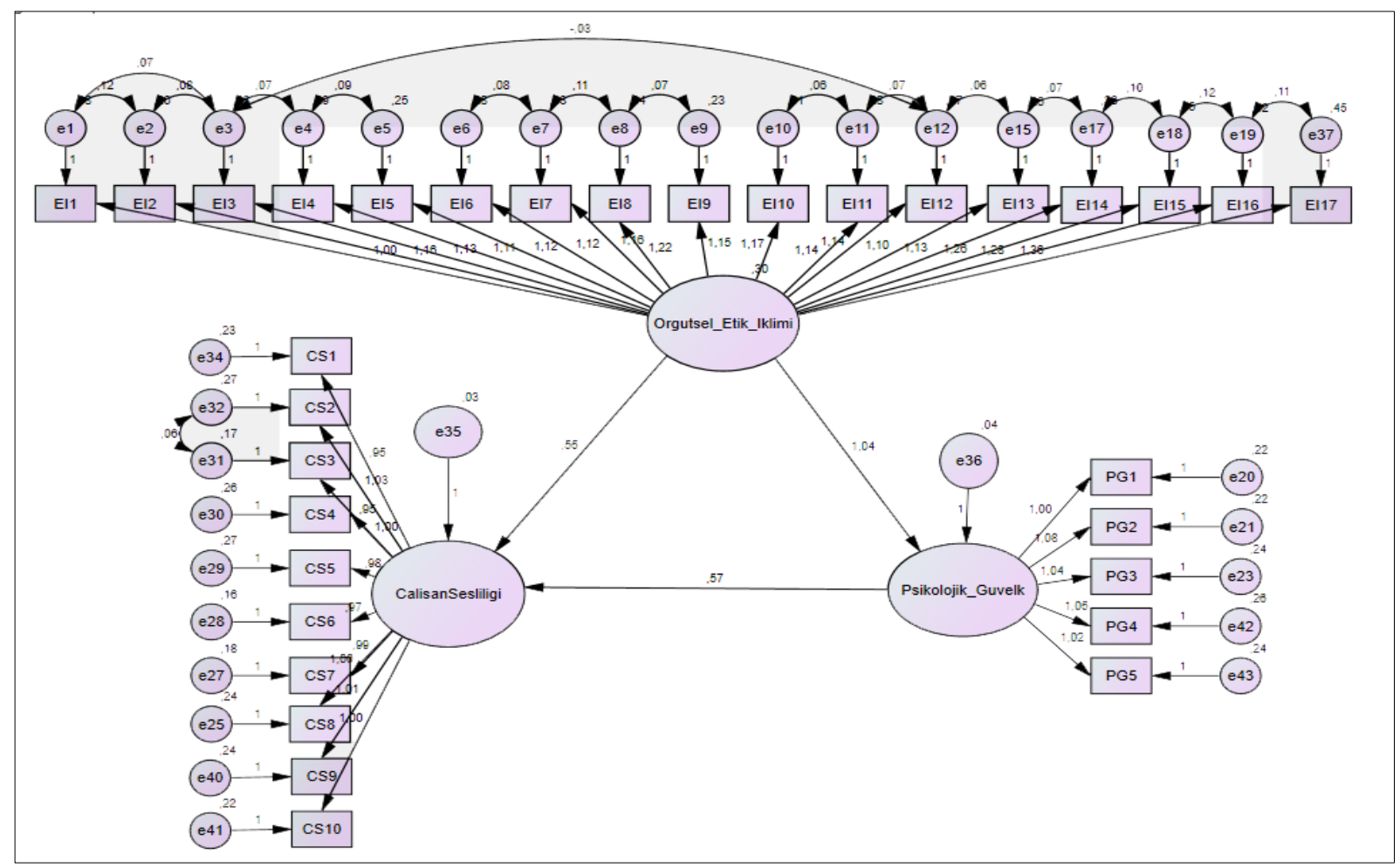

Modelin Uyum İyiliği Değerleri: $\chi^{2} / \mathrm{df}=1,849$; GFI= $.86 \mathrm{NFI}=.90$ TLI=.95; CFI=.95; TLI=.94 RMSEA=.054

Doğrulayıcı faktör analizi sonucunda örgütsel etik iklimine ait 18. ve 19. Sorular, standartlaştırılmış faktör yüklerinin düşük olması nedeniyle analiz kapsamından çıkarılmıştır. Akabinde model tekrar test edilmiştir. Daha sonra tek faktörlü model uygulaması yapılarak araştırma modeli ile tek faktörlü model arasında karşılaştırma yapılmıştır. Elde edilen değerler Tablo 1'de gösterilmektedir.

Tablo 1: Model-Veri Uyum Değerleri

\begin{tabular}{lccccccccc}
\hline & $\mathrm{X}^{2}$ & $\Delta \mathrm{X}^{2}$ & $\mathrm{SD}$ & $\mathrm{X}^{2} / \mathrm{df}$ & GFI & NFI & CFI & TLI & RMSEA \\
\hline $\begin{array}{l}\text { Tek faktörlü } \\
\text { model }\end{array}$ & 1462,40 & - & 464 & 3.15 & .446 & .532 & .579 & .570 & .106 \\
$\begin{array}{l}\text { Araştırma } \\
\begin{array}{l}\text { Modeli } \\
\text { p<0.01 }\end{array}\end{array}$ & 820,94 & 641,46 & 444 & 1.84 & .860 & .906 & .954 & .949 & .054 \\
\hline
\end{tabular}

*RMSEA (Root mean square error of approximation); 0.08 altında iyi bir model kabul edilir (Browne ve Cudeck, 1993)

$\chi^{2} /$ SD (Relative Ki-Kare); 1 ile 5 arasında olmalıdır (Marsh ve Hocevar, 1985)

GFI (Goodness of fit index); l'e yakın olursa iyi bir model kabul edilir (Tanaka ve Huba, 1985)

NFI (Normated fit index); l'e yakın olursa iyi bir model kabul edilir (Bentler ve Bonett, 1980)

CFI (Comperative fit index); l'e yakın olursa iyi bir model kabul edilir (McDonald ve Marsh, 1990)

TLI (Tucker-Lewis indeksi); l'e yakın olursa iyi bir model kabul edilir (Bentler ve Bonett, 1980) 
Tablo 1'deki doğrulayıcı faktör analizi sonucuna göre araştırma verileri 3 ölçme modeline dağıtılarak test edilmiştir. Modele ilişkin RMSEA, GFI, NFI, CFI, TLI ve $\chi 2 / S D$ uyum indeksleri ile elde edilen sonuçlar ile iyi uyum geçerlilik ölçüleri gösterilmektedir. Tablo 1'de 3 faktörlü modele göre $\chi 2$ değerinin anlamlı olduğu belirlenmiştir $(\mathrm{p}<0.01)$. Ayrıca $\chi 2 / \mathrm{SD}$ değerinin $(1,84)$ 5'in altında olması nedeniyle modelin geçerlilik açısından uyumlu olduğu görülmektedir. Araştırma modelleri uyum indeksleri GFI $=0.860, \mathrm{NFI}=0.906, \mathrm{CFI}$ $=0.954, \mathrm{TLI}=0.949$ ve RMSEA $=0.054$ olması nedeniyle modelin uyumlu olduğu görülmektedir. Buna ek olarak yine aynı tabloda (Tablo 1) tek faktörlü model ile araştırmanın üç faktörlü modeli arasında yapılan karşılaştırmada anlamlı fark1 belirleyebilmek için $\chi 2$ değerlerine Ki Kare Testi uygulanmış ve iki değer arasında anlamlı fark belirlenmiştir. Bu sonuçlara göre araştırmada ortak yöntem sapmasının olmadığ1 görülmektedir (MacKenzie ve Podsakoff, 2012).

Tablo 2. Değişkenlere Ait Ortalama, Standart Sapma ve Korelasyon Değerleri

\begin{tabular}{lccccccc}
\hline & Ort & S. S & CR(t) & AVE & 1 & 2 & 3 \\
\hline Örgütsel Etik İklimi & 3,76 & 0,760 & 0,893 & 0,625 & - & & \\
Çalışan Sesliliği & 3,73 & 0,774 & 0,959 & 0,579 & $0,790 * *$ & - & - \\
Psikolojik Güvenlik & 3,66 & 0,765 & 0,951 & 0,662 & $0,762 * *$ & $0,772 * *$ & -
\end{tabular}

Araştırma modeli ile değişkenlerin uyumluluğu ve ölçümü sağlayıp sağlamadığını belirlemek amacıyla yakınsama (convergent validity) ve ıraksama (discriminant validity) geçerlilik tekniklerinden yararlanılmıştır. Hair ve diğ. (2006)'ne göre bir araştırmada ölçek maddelerinin faktör yüklerinin 0,5 değerinden yüksek olması araştırma modelinin ölçme ölçütünü sağladığını göstermektedir. Bu kapsamda araştırma ifade ölçeklerine ait maddelerin standartlaştırılmış faktör yükleri 0,5 değeri üzerindedir. Buna ek olarak, faktör yüklerinin parametrik değerleme noktasında t değerleri 10,61 ile 13,34 arasında değişmektedir (Şekil 2). Bu değerlere göre araştırma modeli anlamlı olarak görülmektedir (Hair vd., 2006).

Araştırma modelinin analizindeki ortalama açıklanan varyans (AVE) değerinin 0,5 değerinden yüksek olması yakınsama geçerliliğinin kanıtı olarak gösterilmektedir (Fornell ve Larcker, 1981). Bu kapsamda her üç ölçeğin AVE değerlerinin 0,5 değerinden yüksek olduğu görülmektedir. Ayırt edici geçerlilik (discriminant validity) için araştırma ölçeklerinin birbirleri arasındaki korelasyon değerlerinin 0,80 'den düşük olması gerekmektedir (Kline, 2014). Tablo 2'ye göre, ilgili ölçeklerden elde edilen yapı güvenirliğinin (CR), her iki güvenirlik düzeyinin 0.70 'den yüksek olması ölçme sonuçlarının güvenirliğinin bir kanıtı olarak ifade edilmektedir (Fornell ve Larcker, 1981; Hair vd., 2006).

\section{BULGULAR}

\subsection{Demografik Bulgular}

Araştırmadaki katılımcıların cinsiyet, eğitim düzeyi, yaş ve kıdem gibi demografik bilgileri, Tablo 3’te açıklanmaktadır.

Tablo 3. Araştırmaya Katılan Kişilere İlişsin Demografik Verilerin Dağılımı

\begin{tabular}{|c|c|c|c|c|c|}
\hline Değişkenler & Sıklık (N) & $\begin{array}{c}\text { Yüzde Değeri } \\
(\%)\end{array}$ & Değişkenler & $\begin{array}{c}\text { Sıklık } \\
(\mathbf{N})\end{array}$ & $\begin{array}{c}\text { Yüzde Değeri } \\
(\%)\end{array}$ \\
\hline Cinsiyet & & & Medeni Durum & & \\
\hline Kadın & 132 & 45,7 & Evli & 223 & 77,2 \\
\hline Erkek & 157 & 54,3 & Bekâr & 66 & 22,8 \\
\hline TOPLAM & 289 & & TOPLAM & 289 & \\
\hline Eğitim Durumu & & & Yaș & & \\
\hline İlköğretim & 6 & 2,1 & $18-25$ yaş arası & 99 & 34,3 \\
\hline Lise & 53 & 18,3 & $26-35$ yaş arası & 94 & 32,5 \\
\hline Lisans & 183 & 63,3 & $36-45$ yaş arası & 81 & 28,0 \\
\hline Lisansüstü & 47 & 16,3 & $46-55$ yaş arası & 15 & 5,2 \\
\hline TOPLAM & 289 & & TOPLAM & 289 & \\
\hline
\end{tabular}

Tablo 3'te katılımcıların \%45,7'si kadınlardan, \%54,3'ü erkeklerden oluşmaktadır. Katılımcıların medeni durumlarına bakıldığında \%77,2'sinin evli, \%22,8'inin ise bekâr olduğu belirlenmiştir. Eğitim düzeylerine göre dağılım incelendiğinde katılımcıların \%63,3'ünün lisans derecesinde olduğu ve bu derecede yoğunlaştıkları görülmektedir. Diğer dağılımlarda ise katılımcıların \%2,1'i ilköğretim, \%18,3'ünün lise ve 
\%16,3'ünün ise lisansüstü derecesine sahip oldukları belirlenmiştir. Yaş aralığına göre katılımcıların \%34,3 oranıyla, 18-55 yaş aralığında yoğunlaştıkları görülmektedir. Diğer yaş oranlarına göre katılımcıların \%32,5'inin 26-35 yaş, \%28'i 36-45 yaş ve \%5,2'si ise 46-55 yaş aralığında personelleri kapsamaktadır.

\subsection{Araştırma Hipotezlerinin Test Edilmesi}

Araştırma hipotezlerinin test edilebilmesi için araştırma verilerine yapısal eşitlik modeli uygulanmıştır. Tablo 5'te yapısal eşitlik modeli analizi sonucunda doğrudan etki sonuçları belirtilmektedir.

Tablo 5. Doğrudan etki

\begin{tabular}{|c|c|c|c|c|}
\hline Değişkenler & $\beta$ & t değeri & $\mathrm{SH}$ & $\mathrm{p}$ \\
\hline Örgütsel Etik İklimi - Çalışan Sesliliği & .547 & 3.394 & .161 & $* * *$ \\
\hline Psikolojik Güvenlik - Çalışan Sesliliği & .574 & 3.892 & .148 & $* * *$ \\
\hline Örgütsel Etik İklimi - Psikolojik Güvenlik & .940 & 11.744 & .089 & $* * *$ \\
\hline
\end{tabular}

Tablo 5'e göre örgütsel etik ikliminin çalışan sesliliği üzerinde pozitif yönlü anlamlı etkisinin olduğu görülmektedir $(\beta=.547, \mathrm{t}=3.394, \mathrm{p}<0.001)$. H1 hipotezi desteklenmektedir. Araştırmanın ikinci hipotezine göre psikolojik güvenliğin çalışan sesliliği üzerinde pozitif yönlü anlamlı etkisinin bulunduğu görülmektedir $(\beta=.574, t=3.892, p<0.001)$. $\mathbf{H 2}$ hipotezi desteklenmektedir. Araştırmanın üçüncü hipotezinde örgütsel etik ikliminin psikolojik güvenlik üzerinde pozitif yönlü anlamlı etkisinin olduğu belirlenmiştir $(\beta=.940, t=11.744$, $\mathrm{p}<0.001)$. H3 hipotezi desteklenmektedir.

Araştırmanın dördüncü hipotezinde örgütsel etik ikliminin çalışan sesliliğine etkisinde psikolojik güvenliğin aracı rolü incelenmektedir. MacKinnon ve diğ. (2007: 594)'ne göre aracı değişken, iki değişken arasında bulunan neden sonuç ilişkisini belirlemek amacıyla kullanılan analiz yöntemidir. Baron ve Kenny (1986)'ye göre araştırmada aracılık etkisinin ölçülmesi için; 1) Bağımsız değişkenin aracı değişken üzerinde etkisi olmalıdır. 2) Bağımsız değişkenin bağımlı değişken üzerinde etkisi olmalıdır. 3) Aracı değişkenin bağımlı değişken üzerinde etkisi olmalıdır. Bu bilgiler ışığında son olarak araştırmanın hipotezlerine yönelik doğrudan etki akabinde aracı etkiye bakılmıştır (Tablo 6).

\section{Tablo 6. Aracı Etki}

\begin{tabular}{|c|c|c|c|c|c|c|c|}
\hline & $\begin{array}{l}\text { Toplam } \\
\text { Etki }\end{array}$ & $\begin{array}{l}\text { Doğrudan } \\
\text { Etki }\end{array}$ & $\begin{array}{l}\text { Arac1 } \\
\text { Etki }\end{array}$ & $\begin{array}{c}\text { Alt } \\
\text { Sinir }\end{array}$ & $\begin{array}{c}\text { Üst } \\
\text { Sinır }\end{array}$ & $\mathrm{p}$ & Sonuç \\
\hline $\begin{array}{l}\text { Örgütsel Etik İklimi - } \\
\text { Psikolojik Güvenlik }\end{array}$ & 0.947 & 0.947 & - & - & - & - & \\
\hline $\begin{array}{l}\text { Örgütsel Etik İklimi - } \\
\text { Çalışan Sesliliği }\end{array}$ & 0.946 & 0.452 & 0.494 & 0.167 & 0.865 & 0.04 & $\begin{array}{c}\text { Aracı } \\
\text { Etki var } \\
\text { (kismi) } \\
\mathrm{R}^{2}: \% 74\end{array}$ \\
\hline $\begin{array}{l}\text { Psikolojik Güvenlik - } \\
\text { Çalışan Sesliliği }\end{array}$ & 0.521 & 0.521 & - & - & - & - & \\
\hline
\end{tabular}

Tablo 6’ya göre \%95 güven aralığında örgütsel etik iklimi ile çalışan sesliliği arasındaki ilişkide psikolojik güvenlik aracı rol oynamaktadır ( $\mathrm{p}=0.04<0.05$ ). Güven aralığı alt sınır $=0,167$ ile üst sınır $=0,865$ ve açıklanan varyans oranı ise $\% 74$ olarak belirlenmiştir. Bu kapsamda örgütsel etik ikliminin çalışan sesliliğine etkisinde psikolojik güvenliğin kısmi aracılık rolü oynadığı görülmektedir. H4 hipotezi desteklenmektedir.

\section{SONUÇ VE TARTIŞMA}

Örgütsel etik ikliminin çalışan sesliliğine etkisinde psikolojik güvenlik algısının aracı rolüne yönelik bu araştırmada etik kurallar çerçevesinde olumlu bir örgüt ortamı oluşturmanın çalışan sesliliğini güçlendireceği görülmektedir. Sosyal mübadele kuramına göre ela alınan bu araştırmada olumlu örgütsel ortamlarda meydana gelen örgütsel etik ikliminin çalışanlarda seslilik algısını arttırdığını ve bundan dolayı örgütsel etik iklimi ve çalışan sesliliği etkileşiminde psikolojik güvenliğin aracı rol oynadığı anlaşılmaktadır. Araştırma bulgularına dayanarak çalışan sesliliğini sağlayan örgüt koşullarında etik iklimin oluşturulması psikolojik güvenlik algısını güçlendirmektedir. Psikolojik güvenliğin de çalışan sesliliğini arttırdığını göstermesi nedeniyle bu üç örgüt 
davranışının birbirlerini olumlu yönde etkilediği ileri sürülebilir. Araştırma bulguları örgütsel etik ikliminin, çalışan sesliliği ve psikolojik güvenliği olumlu yönde güçlendirmesi ile iş tatmini, örgütsel bağl1lık, örgütlerde güven gibi örgütleri olumlu yönde etkileyen diğer olumlu değişkenlerle olumlu örgüt davranışlarını teşvik etmesi ihtimalleri bakımından önemlidir.

Araştırma kapsamında Konya ilinde bulunan iki adet vakıf üniversitesindeki idari personellere yönelik örgütsel etik iklimi, çalışan sesliliği ve psikolojik güvenlik etkileşimlerini belirlemek amacıyla uygulama yapılmıştır. Bu çerçevede "örgütsel etik ikliminin çalışan sesliliğine etkisinde psikolojik güvenlik aracı bir işleve sahip midir" sorusuna cevap aranmıştır. Araştırma sorusunu cevaplayabilmek için kurgulanan hipotezlerin tümünün desteklendiği belirlenmiştir. Bu kapsamda örgütsel etik iklimi, çalışan sesliliği ve psikolojik güvenlik algısı birbirlerini pozitif yönde etkilemektedir. Soyalin ve Karabey (2020), Siirt ilinde görev yapmakta olan sağlık çalışanlarına yönelik araştırmalarında her üç değişkenin de birbirlerini pozitif yönde etkilediğini belirlemişlerdir. Bununla birlikte araştırma bulguları literatüre göre daha kapsamlı bir şekilde aşağıda belirtilmektedir;

- Araştırma değişkenlerinden örgütsel etik ikliminin çalışan sesliliğini pozitif yönde etkilediği belirlenmiştir $(p<0,001)$. Meydan ve diğ. (2016), Ankara'daki bir kamu kurumunda yaptıkları araştırmada çalışan sessizliğini ele alarak örgütlerde etik ikliminin artmasıyla çalışan sessizliğinin azalacağını belirlemişlerdir. Bu araştırma çalışan sesliliği açısından ele alındığında etik iklimin çalışan sesliliğini pozitif yönde etkileyeceği yorumu yapılabilir. Qi ve Liu (2017) Çin'deki çeşitli kuruluş çalışanlarına yönelik yaptıkları araştırmada örgütsel etik ikliminin çalışan sesliliğini olumlu yönde etkilediğini belirlemişlerdir. Peng ve Wei (2019) Çinli yönetici ve çalışanlara yönelik yaptıkları araştırmada çalışan sesliliğinin örgütsel iklimden etkilendiğini belirleyerek etik değerlerin çalışan sesliliğini arttırdığını ifade etmektedirler. $\mathrm{Bu}$ kapsamda literatürdeki bulgularla araştırmanın ilk hipotez bulguları örtüşmektedir.

- Araştırmanın ikinci hipotezinde psikolojik güvenliğin çalışan sesliliğini pozitif yönde etkilediği belirlenmiştir $(\mathrm{p}<0,001)$. Yin (2013), Hong Kong’taki bir işletmede yarı zamanlı personellere yönelik yaptı̆̆ araştırmada psikolojik güvenlik algısının çalışan sesliliğini olumlu yönde etkilediğini belirlemiştir. Lee ve diğ. (2017) Güney Kore'deki bir işletmede beyaz yakalı çalışanlara yönelik yaptıkları araştırmada etik iklimin desteklendiği örgütlerde çalışanların fikirlerini rahatlıkla dile getirdiklerini belirlemişlerdir. Ding ve diğ. (2019) bir kurumdaki çalışanları denetleyenler ile çalışanlar arasında yaptıkları araştırmada psikolojik güvenliğin, çalışanın ses davranışını olumlu yönde etkilediğini belirlemişlerdir. Miao ve diğ. (2020) Çin'deki kurumların insan kaynakları yöneticileri ile çalışanlarına yönelik yaptıkları araştırmada psikolojik güvenliğin çalışan sesliliğini teşvik ettiğini belirlemişlerdir. Bu kapsamda araştırmanın ikinci hipotezine yönelik bulgular ile literatür paralellik göstermektedir.

- Araştırmanın üçüncü hipotezinde örgütsel etik iklimi psikolojik güvenliği pozitif yönde etkilemektedir $(\mathrm{p}<0,001)$. Simha ve Stachowicz-Stanusch (2015) Polonya'daki bir hastanede görev yapmakta olan yöneticilere yönelik yaptıkları araştırmada örgütsel etik ikliminin psikolojik güveni pozitif yönde etkilediğini belirlemişlerdir. Simha ve Pandey (2020) Hindistan'daki bir hastanede çalışan hemşirelere yönelik yaptıkları araştırmada örgütsel etik ikliminin güveni olumlu yönde etkilediğini belirlemişlerdir. Diğer yanda literatürdeki bu bulguların aksine Filiz ve Bardakçı (2020) yaptıkları araştırmada örgütsel etik iklimi ile psikolojik güvenlik arasında anlamlı bir farklılı̆̆ın bulunmadığını belirlemişlerdir. Bu doğrultuda araştırmanın üçüncü hipotez bulgularının literatürle kısmen örtüştüğü söylenebilir.

- Araştırmanın son hipotezine göre örgütsel etik ikliminin çalışan sesliliğine etkisinde psikolojik güvenin kısmen aracılık etkisinin olduğu sonucuna ulaşılmıştır $\left(p=0,04<0,05 ; \mathrm{R}^{2}=\% 74\right)$. Walumbwa ve Schaubroeck (2009) Amerika'daki bir finans şirketi çalışanlarına yönelik yaptıkları araştırmada psikolojik güvenliğin, etik liderlik ile çalışan sesliliği etkileşiminde kısmi aracılık rolü üstlendiğini belirlemişlerdir. Potipiroon ve Wongpreedee (2020) Tayland'da yerel yönetime ait bir kurumdaki çalışanlara yönelik yaptıkları araştırmada örgütsel etik ikliminin bilgi ifşa davranışına etkisinde psikolojik güvenliğin aracı değişken olarak etkilediğini belirlemişlerdir. Literatürdeki bilgiler ile araştırmanın son hipotezine yönelik elde edilen bulgular da örtüşmektedir.

Konu üzerine yapılan araştırmalarda örgütsel etik iklimi ve psikolojik güven algısı gibi durumların örgütler açısından olumlu durumlar olduğu görülmektedir. Araştırma bulgularına göre çalışanların, güven duydukları örgüt ortamlarında ve etik ilkelerle yönetilen örgütlerde görüşlerini açıkça ve korkmadan belirtecekleri anlaşılmıştır. Diğer yandan çalışanların, güven duymadıkları örgüt ortamlarında fikirlerini söylemekten kaçınacakları ve örgütsel sessizlik yaşayacakları söylenebilir. Ayrıca örgütsel etik iklimi ile çalışan sesliliği arasındaki pozitif ve anlamlı etkileşim olması, örgütsel etik iklimi ve çalışan sesliliği gibi durumların psikolojik güveni güçlendiren duygu etkenleri olduğunu de göstermektedir. Bu bilgiler 1şığında örgütsel etik ikliminin çalışan sesliliğini; psikolojik güvenliğin çalışan sesliliğini; örgütsel etik ikliminin psikolojik 
güvenliği pozitif yönde etkilemesi kurgulanan hipotezlerin kabul edildiğini ve araştırma modelinin geçerli olduğunu göstermektedir. Diğer yandan örgütlerdeki olumlu davranış biçimleri ve durumların örgütlerin verimliliğini arttırdığı düşüncesiyle örgütlerin olumluluğuna etki eden birçok nedenin bulunduğu da göz ardı edilmemelidir. $\mathrm{Bu}$ sonuçlar doğrultusunda araştırmanın pratik çıkarsamaları bakımından önemli olduğu düşünülmekle birlikte örgütlerdeki olumlu duygu ve davranış durumlarının diğer olumlu davranışlar olan örgütsel aidiyet, örgütsel vatandaşlık, iş tatmini, örgütsel özdeşleşme gibi örgütü olumlu yönde etkileyen yaklaşımlarla da destekleneceği düşünülmektedir.

Araştırma kapsamında yapılan uygulama örgütsel etik ikliminin çalışan sesliğine etkisinde psikolojik güvenin aracı bir rol oynayıp oynamamasını incelemekle sınırlı olup Konya ilindeki vakıf üniversitelerinde görev yapmakta olan idari personellerle ve nicel araştırma yöntemine göre tasarlanmış sınırlı bir araştırma özelliği göstermektedir. Araştırma örgütsel davranışın diğer olumlu konuları olan iş tatmini, örgütsel adalet, örgütsel aidiyet gibi değişkenlerle farklı örneklemlerde tekrarlanabileceği gibi örgütsel davranışın negatif değişkenleri olan örgütsel sinizim, geride kalanlar sendromu, örgütsel dışlanma gibi konularla da etkileşimleri incelenebilir. Diğer yandan araştırmanın aracı değişkeni olan psikolojik güvenlik algısının bu ilişkide düzenleyici işlev görüp görmediği de gelecek çalışmalarda araştırmacılara öneri niteliğinde olmaktadır. Buna ek olarak konunun daha iyi anlaşılabilmesi açısından nitel araştırma yapılarak karma yöntemininde tercih edilmesiyle konunun daha derinlemesine irdelenmesi öneri niteliğinde olmaktadır. 


\section{KAYNAKÇA}

Akdoğan, Asuman ve Demirtaş, Özgür, (2014) “Etik Liderlik Davranışlarının Etik İklim Üzerindeki Etkisi: Örgütsel Politik Algılamaların Aracı Rolü”, Afyon Kocatepe Üniversitesi İktisadi ve İdari Bilimler Fakültesi Dergisi, 16 (1), s.107-24.

Alfayad, Zaid and Arif, Lily Suriani Mohd, (2017) "Employee voice and job satisfaction: An application of Herzberg two-factor theory", International Review of Management and Marketing, 7 (1), s.150-56.

Arnaud, Anke, (2010) "Conceptualizing and measuring ethical work climate: Development and validation of the ethical climate index", Business \& Society, 49 (2), s.345-58.

Ashford, Susan J ve diğ. (1998) Out on a limb: The role of context and impression management in selling gender-equity issues, Administrative Science Quarterly, s.23-57.

Aydın, İnayet (2001) Yönetsel Mesleki ve Örgütsel Etik, Pegem Yayıncılık.

Baron, Reuben M and Kenny, David A, (1986) "The moderator-mediator variable distinction in social psychological research: Conceptual, strategic, and statistical considerations", Journal of personality and social psychology, 51 (6), 1173.

Baş, Türker (2003), Anket: anket nasıl hazırlanır?: anket nasıl uygulanır? (Seçkin yayıncılık).

Bentler, Peter M and Bonett, Douglas G, (1980) Significance tests and goodness of fit in the analysis of covariance structures, Psychological bulletin, 88 (3), 588.

Bowen, Frances and Blackmon, Kate, (2003) "Spirals of silence: The dynamic effects of diversity on organizational voice", Journal of management Studies, 40 (6), s.1393-417.

Brown, Michael E and Treviño, Linda K, (2006) "Ethical leadership: A review and future directions", The leadership quarterly, 17 (6), s.595-616.

Brown, Michael E, Treviño, Linda K, and Harrison, David A, (2005) "Ethical leadership: A social learning perspective for construct development and testing”, Organizational behavior and human decision processes, 97 (2), s.117-34.

Browne, M. W. and Cudeck, Robert, (1993) Alternative ways of assessing model fit, Testing structural equation models, 154, 136.

Burris, Ethan R, Detert, James R, and Chiaburu, Dan S, (2008) "Quitting before leaving: the mediating effects of psychological attachment and detachment on voice", Journal of Applied Psychology, 93 (4), 912.

Carnevale, David G, (1988) Organizational trust: A test of a model of its determinants, (Florida State University).

Chen, H., Chau, Patrick YK, and Li, Wenli, (2019a) The effects of moral disengagement and organizational ethical climate on insiders" information security policy violation behavior, Information Technology \& People.

Chen, Silu, ve diğ. (2019b), Spiritual leadership on proactive workplace behavior: the role of organizational identification and psychological safety, Frontiers in psychology, 10, 1206.

Cullen, John B, Parboteeah, K Praveen, and Victor, Bart, (2003) "The effects of ethical climates on organizational commitment: A two-study analysis, Journal of Business Ethics, 46 (2), s.127-41.

Çiftçi, Gamze Ebru ve Gürer, Alper, (2019) "Özgecilik Davranışııın Bireysel Performans Üzerindeki Etkisinde Çalışan Sesliliğinin Aracı Rolü”, Journal of Social Sciences/Sosyal Bilimler Dergisi (2146-4561), 9 (17).

Dahl, Kari Kragh Blume, (2020) "Mo (ve) ments in professional identification: achieving professional identity and becoming a teacher in Danish and Kenyan teacher education", Compare: A Journal of Comparative and International Education, 50 (1), s.123-40.

DeConinck, James B, (2011) "The effects of ethical climate on organizational identification, supervisory trust, and turnover among salespeople", Journal of Business Research, 64 (6), s.617-24.

Ding, Wanyi, Chang, Po-Chien, and Mi, Sha, (2019) "The Influence of Humble Leadership on Employee Voice Behavior: Psychological Security as a Mediator", 4th International Conference on Humanities Science, Management and Education Technology (HSMET 2019) (Atlantis Press).

Doğan, Selen ve Kılıç, Selçuk, (2014) "Algıllanan örgütsel etik iklim ve üretkenlik karşııı iş davranışları arasındaki ilişkilerin incelenmesi”, Cumhuriyet Üniversitesi İktisadi ve İdari Bilimler Dergisi, 15 (1), s.269-92.

Dyne, Linn Van, Ang, Soon, and Botero, Isabel C, (2003) "Conceptualizing employee silence and employee voice as multidimensional constructs", Journal of management studies, 40 (6), s.1359-92.

Edmondson, Amy C, (2002) Managing the risk of learning: Psychological safety in work teams (Citeseer).

Edmondson, Amy C and Lei, Zhike, (2014) "Psychological safety: The history, renaissance, and future of an interpersonal construct", Annu. Rev. Organ. Psychol. Organ. Behav., 1 (1), s.23-43.

Elçi, Meral ve Alpkan, Lütfihak, (2006) "Etik İklimin Örgütsel Vatandaşlık Davranışlarına Etkileri”, Hacettepe Üniversitesi İktisadi ve İdari Bilimler Fakültesi Dergisi, 24 (1), s.141-70.

Erkutlu, Hakan and Chafra, Jamel, (2015) "The mediating roles of psychological safety and employee voice on the relationship between conflict management styles and organizational identification", American Journal of Business.

Ertürk, Ebru, (2014) "Sosyal mübadele teorisi bağlamında güç mesafesi ve örgütsel adalet algılamalarının örgütsel vatandaşlık davranışı üzerindeki etkisi”, (Selçuk Üniversitesi Sosyal Bilimler Enstitüsü).

Farndale, Elaine, ve diğ. (2011) "The influence of perceived employee voice on organizational commitment: An exchange perspective", Human Resource Management, 50 (1), s.113-29.

Filiz, Mustafa ve Bardakçı, Sait, (2020) "Sağlık Çalı̧̧anlarının Örgütsel İklim Algıları Ve Örgütsel Güven Düzeyleri Arasındaki İlişkinin İncelenmesi: Artvin İli Örneği”, Electronic Journal of Social Sciences, 19 (73). 
Fornell, Claes and Larcker, David F (1981) "Evaluating structural equation models with unobservable variables and measurement error", Journal of marketing research, 18 (1), s.39-50.

Hair, Joseph F, ve diğ. (2006) "Multivariate data analysis . Uppersaddle River", (NJ: Pearson Prentice Hall).

Haldorai, Kavitha, ve diğ. (2020) "Workplace spirituality as a mediator between ethical climate and workplace deviant behavior”, International Journal of Hospitality Management, 86, 102372.

Hirak, Reuven, ve diğ. (2012) "Linking leader inclusiveness to work unit performance: The importance of psychological safety and learning from failures", The Leadership Quarterly, 23 (1), s.107-17.

Hirschman, Albert O, (1970) Exit, voice, and loyalty: Responses to decline in firms, organizations, and states (25: Harvard university press).

Johnson, Craig Edward, (2009) Ethics in the workplace: Tools and tactics for organizational transformation (Sage Publications).

Kahn, William A, (1990) "Psychological conditions of personal engagement and disengagement at work", Academy of management journal, 33 (4), s.692-724.

Kaufman, Bruce E, (2015) “Theorising Determinants Of Employee Voice: An Integrative Model Across Disciplines And Levels Of Analysis. “, Human Resource Management Journal, 1, s.19-40.

Kızbaz, Arzu, (2016) “Reklamda Etik Üzerine Bir Değerlendirme:“Koton Reklamı”“, Manas Sosyal Araştırmalar Dergisi, 5 (2), s.230-46.

Kline, Paul, (2014) An easy guide to factor analysis (Routledge).

Lam, Long W, ve diğ. (2016) "Voice more and stay longer: How ethical leaders influence employee voice and exit intentions", Business Ethics Quarterly, 26 (3), s.277-300.

Landau, Jacqueline, (2009) "When employee voice is met by deaf ears", SAM Advanced Management Journal, 74 (1), 4.

Lee, Dongseop, ve diğ. (2017) "Ethical leadership and employee moral voice: The mediating role of moral efficacy and the moderating role of leader-follower value congruence", Journal of Business Ethics, 141 (1), s.47-57.

Liang, Jian, Farh, Crystal IC, and Farh, Jiing-Lih, (2012) "Psychological antecedents of promotive and prohibitive voice: A two-wave examination”, Academy of Management journal, 55 (1), s.71-92.

MacKenzie, Scott B and Podsakoff, Philip M, (2012) "Common method bias in marketing: Causes, mechanisms, and procedural remedies", Journal of retailing, 88 (4), s.542-55.

MacKinnon, David P, Fairchild, Amanda J, and Fritz, Matthew S (2007), “Mediation analysis”, Annu. Rev. Psychol., 58, s.593-614.

Marsh, Herbert W and Hocevar, Dennis, (1985) "Application of confirmatory factor analysis to the study of self-concept: First-and higher order factor models and their invariance across groups", Psychological bulletin, 97 (3), 562.

May, Douglas R, Gilson, Richard L, and Harter, Lynn M (2004), "The psychological conditions of meaningfulness, safety and availability and the engagement of the human spirit at work", Journal of occupational and organizational psychology, 77 (1), s.11-37.

McDonald, Roderick P and Marsh, Herbert W, (1990) "Choosing a multivariate model: Noncentrality and goodness of fit”, Psychological bulletin, 107 (2), 247.

Meydan, Cem Harun, Köksal, Kemal, ve Uğurlu Kara, Arzu, (2016) “Örgüt içinde sessizlik: Örgütsel etik değerlerin etkisi ve adalet algisinin aracilik rolü”, İktisadi ve İdari Bilimler Fakültesi Dergisi, 17 (3), s.142-59.

Miao, Rentao, ve diğ. (2020) "The High-Performance Work System, Employee Voice, and Innovative Behavior: The Moderating Role of Psychological Safety”, International Journal of Environmental Research and Public Health, 17 (4), 1150.

Milliken, Frances J, Morrison, Elizabeth W, and Hewlin, Patricia F, (2003) “An exploratory study of employee silence: Issues that employees don't communicate upward and why", Journal of management studies, 40 (6), s.1453-76.

Morrison, Elizabeth Wolef, (2011) "Employee voice behavior: Integration and directions for future research", Academy of Management annals, 5 (1), s.373-412.

Morrison, Elizabeth Wolef, (2014) Employee voice and silence. Annu. Rev. Organ. Psychol. Organ. Behav., 1(1), s.173197.

Morrison, Elizabeth Wolef and Milliken, Frances J, (2000) “Organizational silence: A barrier to change and development in a pluralistic world”, Academy of Management review, 25 (4), s.706-25.

Nazir, Sajjad, ve diğ. (2020), "Linking paternalistic leadership to follower's innovative work behavior: the influence of leader-member exchange and employee voice", European Journal of Innovation Management.

Öztürk, Namık Kemal ve Coşkun, Bayram, (2000) "Kamu yönetiminde yeniden yapılanma ve kamu hizmetlerinde kalite: Etiksel bir bakış", Türk İdare Dergisi, 72 (426).

Pearsall, Matthew J and Ellis, Aleksander PJ, (2011) "Thick as thieves: the effects of ethical orientation and psychological safety on unethical team behavior", Journal of Applied Psychology, 96 (2), 401.

Peng, He and Wei, Feng, (2019) "How and when does leader behavioral integrity influence employee voice? the roles of team independence climate and corporate ethical values", Journal of Business Ethics, s.1-17.

Peterson, Dane K, (2002) "Deviant workplace behavior and the organization's ethical climate", Journal of business and psychology, 17 (1), s.47-61. 
Potipiroon, Wisanupong and Wongpreedee, Achakorn, (2020) "Ethical Climate and Whistleblowing Intentions: Testing the Mediating Roles of Public Service Motivation and Psychological Safety Among Local Government Employees", Public Personnel Management, 0091026020944547.

Prasadika, GHHP and Nishanthi, HM, (2018) "Perceived employee voice and organizational commitment: a case of Sri Lanka", Asian Journal of Empirical Research, 8 (9), s.330-41.

Qi, Lei and Liu, Bing, (2017) "Effects of inclusive leadership on employee voice behavior and team performance: the mediating role of caring ethical climate", Frontiers in Communication, 2, 8.

Rich, Ryan M, ve diğ. (2006) "Short-term safety and efficacy of intravitreal bevacizumab (Avastin) for neovascular agerelated macular degeneration", Retina, 26 (5), s.495-511.

Ring, Peter Smith and Van de Ven, Andrew H, (1992) "Structuring cooperative relationships between organizations", Strategic management journal, 13 (7), s.483-98.

Rubbab, Um-e and Naqvi, Sayyed Muhammad Mehdi Raza, (2020) "Employee voice behavior as a critical factor for organizational sustainability in the telecommunications industry", PloS one, 15 (9), e0238451.

Rusbult, Caryl E, Zembrodt, Isabella M, and Gunn, Lawanna K, (1982) "Exit, voice, loyalty, and neglect: Responses to dissatisfaction in romantic involvements", Journal of personality and social psychology, 43 (6), 1230.

Ryan, Kathleen D and Oestreich, Daniel K, (1991) Driving fear out of the workplace: How to overcome the invisible barriers to quality, productivity, and innovation (Jossey-Bass).

Sağnak, Mesut, (2017) "Ethical leadership and teachers" voice behavior: The mediating roles of ethical culture and psychological safety", Educational Sciences: Theory \& Practice, 17 (4).

Saunders, David M, (1992) "Introduction to research on Hirschman's Exit, Voice, and Loyalty model”, Employee Responsibilities and Rights Journal, 5 (3), s.187-90.

Saunders, David M, ve diğ. (1992), "Employee voice to supervisors”, Employee Responsibilities and Rights Journal, 5 (3), s.241-59.

Schein, Edgar H and Bennis, Warren G, (1965) Personal and organizational change through group methods: The laboratory approach (Wiley New York).

Sezgili, Konuralp ve Efeoğlu, İbrahim Efe, (2020) "Etik İklimin Boyutlari ve Türleri: Etik Alt İklimlerin Belirlenmesi ve Örgütsel Bağliliğa Etkileri”, Business \& Management Studies: An International Journal, 8 (3), s.3615-39.

Simha, Aditya and Stachowicz-Stanusch, Agata, (2015) "The effects of ethical climates on trust in supervisor and trust in organization in a Polish context", Management Decision.

Simha, Aditya and Pandey, Jatin, (2020) “Trust, ethical climate and nurses' turnover intention”, Nursing Ethics, 0969733020964855.

Soyalin, Mesut ve Karabey, Canan Nur, (2020) “Örgütsel Etik İklim ve Çalışan Sesliliği Davranışı Arasındaki İlişki: Psikolojik Güvenliğin Aracı Rolü”, Business and Economics Research Journal,11(3), s.875-89.

Soyalın, Mesut, (2019) “Örgütsel Etik İklim, Psikolojik Güvenlik, Güç Mesafesi Yönelimi Ve Çalışan Sesliliği Davranışı Arasındaki İlişkiler”, (Atatürk Üniversitesi Sosyal Bilimler Enstitüsü İşletme Anabilim Dalı).

Tanaka, Jeffrey Scott and Huba, George John, (1985) "A fit index for covariance structure models under arbitrary GLS estimation", British journal of mathematical and statistical psychology, 38 (2), s.197-201.

Tangirala, Subrahmaniam and Ramanujam, Rangaraj, (2008) "Exploring nonlinearity in employee voice: The effects of personal control and organizational identification", Academy of Management Journal, 51 (6), s.1189-203.

Thohiroh, Afifah and Satrya, Aryana, (2019) "The Influence of Employee Voice and Employee Resilience to Turnover Intention through Emotional Exhaustion as Mediator on Industrial Garment Workers in Indonesia", International Journal of Scientific \& Engineering Research Volume 10, Issue 1, January-2019 ISSN 2229-5518.

Trevino, Linda Klebe, Butterfield, Kenneth D, and McCabe, Donald L, (1998) "The Ethical Context in Organizations: Influences on Employee Attitudes and Behaviors", Business Ethics Quarterly, 8 (3), s.447-76.

Tuna, Muharrem ve Yeşiltaş, Murat, (2014) "Etik iklim, işe yabancılaşma ve örgütsel özdeşleşmenin işten ayrılma niyeti üzerindeki etkisi: Otel işletmelerinde bir araştırma”, Anatolia: Turizm Araştırmaları Dergisi, 25 (1), s.105-17.

Tutar, Hasan ve Erdem, Ahmet Tuncay, (2020) “Örnekleriyle Bilimsel Araştırma Yöntemleri ve - SPSS Uygulamaları”, (Seçkin Yayncılık).

Victor, Bart and Cullen, John B, (1988) "The organizational bases of ethical work climates", Administrative science quarterly, 101-25.

Walumbwa, Fred O and Schaubroeck, John, (2009) "Leader personality traits and employee voice behavior: mediating roles of ethical leadership and work group psychological safety", Journal of applied psychology, 94 (5), 1275.

Wang, Xin-qiang, ve diğ. (2020) "Implicit professional identity: assessment and relation with explicit professional identity and well-being of pre-service teachers", European Journal of Teacher Education, s.1-18.

Waskito, Jati, ve diğ. (2020) "Does the Social Exchange Theory (SET) Work Effectively for New Employees? An Empirical Study of Contingent Worker in Indonesia”, Pertanika Journal of Social Sciences \& Humanities, 28 (2).

Whiting, Steven W, ve diğ. (2012) "Effects of message, source, and context on evaluations of employee voice behavior", Journal of Applied Psychology, 97 (1), 159.

Wimbush, James C and Shepard, Jon M, (1994) "Toward an understanding of ethical climate: Its relationship to ethical behavior and supervisory influence", Journal of Business ethics, 13 (8), s.637-47.

Yin, Lui Wing, (2013) "Inclusive leadership and employee voice: Mediating roles of psychological safety and leadermember exchange", Unpublished undergraduate thesis). Hong Kong Baptist University. 